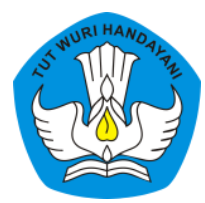

Page: 723-740

\title{
Pengembangan Media Pembelajaran Kincir Angin Berbasis STEM untuk Meningkatkan Keterampilan Mengomunikasikan Siswa Inklusi Kelas 4 Sekolah Dasar
}

\author{
Ida Sri Astutik \\ Sekolah Dasar Minggiran I \\ Contributor Email: ida.sriastutik82@gmail.com
}

Article Url: http://ojsdikdas.kemdikbud.go.id/index.php/didaktika/article/view/132

\begin{abstract}
The purpose of this study is to develop SEM learning media based on SEM (Science, Technology, Engineering and Mathematics), improve communication skills, and find out the effectiveness of using STEM-based windmill learning media in the learning of students with special needs or the inclusion of 4th grade elementary school, because they have different characteristics with other children. Therefore we need a special educational institution so that their abilities can be honed to the maximum. The Inclusion School is an alternative to formal educational institutions that accommodate and direct these children to get to know and understand the knowledge and skills needed in daily life. The ability to communicate with 4 th grade inclusion students in primary schools has not been able to be maximized, this can be known from the average value obtained which is only 66.67. Homework that must be completed immediately and find a solution. So far, educators only use the lecture method and do not involve student activities in the classroom so students are not interested in learning activities. After using the STEM-based learning media, an increase in students' ability to communicate. The results show the average value increased by 19.04 significantly. The previous average value of 66.67 became 85.71. During the learning process it was concluded that the use of STEM-based learning media for windmills could improve the communication skills of 4 th grade inclusion students in elementary schools.
\end{abstract}

Keywords: Learning Media; Windmills; Communication Skills 


\begin{abstract}
Abstrak
Tujuan penelitian ini adalah untuk mengembangkan media pembelajaran kincir angina berbasis SEM (Science, Technology, Engineering and Mathematic), meningkatkan keterampilan mengomunikasikan, dan mengetahui efektifitas penggunaan media pembelajaran kincir angin berbasis STEM) dalam pembelajaran siswa berkebutuhan khusus atau inklusi kelas 4 sekolah dasar, karena mereka memiliki kekhasan yang berbeda dengan anak lainnya. Oleh sebab itu dibutuhkan sebuah lembaga pendidikan khusus agar kemampuan yang mereka miliki bisa terasah dengan maksimal. Sekolah Inklusi merupakan salah satu alternatif lembaga pendidikan formal yang menampung dan mengarahkan anak-anak ini untuk mengenal dan memahami tentang ilmu pengetahuan serta ketrampilan yang dibutuhkan dalam kehidupan sehari-hari. Keterampilan mengomunikasikan pada siswa inklusi kelas 4 sekolah dasar belum bisa maksimal, hal ini dapat diketahui dari nilai rata-rata yang diperoleh yaitu hanya 66,67. Pekerjaan rumah yang harus segera diselesaikan dan dicarikan solusinya. Selama ini pendidik hanya menggunakan metode ceramah dan kurang melibatkan aktivitas siswa di dalam kelas sehingga siswa tidak tertarik dalam kegiatan pembelajaran. Setelah menggunakan media pembelajaran kincir angin berbasis STEM terjadi peningkatan kemampuan siswa dalam mengomunikasikan. Hasill menunjukkan nilai rata-rata meningkat sebesar 19,04 secara signifikan. Nilai rata-rata sebelumnya 66.67 menjadi 85,71. Selama proses pembelajaran disimpulkan bahwa menggunaan media pembelajaran kincir angin berbasis STEM dapat meningkatkan keterampilan mengomunikasikan pada siswa inklusi kelas 4 sekolah dasar.
\end{abstract}

Keywords: Media Pembelajaran; Kincir Angin; Ketrampilan Mengomunikasika

\title{
A. Pendahuluan
}

Pendidikan merupakan suatu kebutuhan bagi setiap warga negara, tanpa pendidikan tidak mungkin adanya transfer ilmu dari pendidik kepada peserta didik. Sesuai dengan Undang-Undang Dasar 1945 pasal 31 ayat 1 yang berbunyi "tiap-tiap warga negara berhak mendapatkan pengajaran" hal ini menegaskan bahwa setiap warga negara di Indonesia tanpa terkecuali mempunyai hak yang sama dalam belajar dan pembelajaran. Dalam Sistem Pendidikan Nasional pasal 5 ayat 1 juga disebutkan bahwa warga negara Indonesia mempunyai hak yang sama untuk memperoleh pendidikan yang bermutu. Pada ayat 2 juga lebih ditegaskan lagi bahwa warga negara yang memiliki kelainan fisik, emosional, mental, intelektual dan atau sosial berhak memperoleh pendidikan khusus. 
Banyaknya anggapan bahwa anak-anak yang memiliki kebutuhan khusus adalah anak yang berbeda dengan anak-anak yang normal. Hal ini menyebabkan mereka seperti tidak diindahkan dalam kehidupan bermasyarakat. Adanya diskriminasi bagi anak-anak berkebutuhan khusus menyebabkan mereka tidak mendapatkan pendidikan yang layak dan bermutu $\mathrm{Hal}$ inilah yang mendasari terselenggaranya sekolah inklusi di lingkungan pendidikan kita.

Pendidikan inklusi merupakan layanan pendidikan yang memberikan keleluasaan peserta didik untuk belajar bersama-sama di sekolah formal dengan tetap memperhatikan kekhasan, keragaman dan kebutuhan individual sehingga bakat dan potensi peserta didik bisa berkembang secara maksimal (Indiyanto, 2013:9). Anak-anak berkebutuhan khusus tetap bisa mendapatkan pendidikan bersama dengan anak normal lainnya dalam satu lembaga pendidikan yang sama walaupun ada beberapa hal yang harus lebih diperhatikan oleh pendidik dalam menyampaikan materi serta sistem penilaian yang tidak merugikan hak peserta didik untuk belajar.

Siswa berkebutuhan khusus di kelas 4 cenderung kurang bisa mengomunikasikan sesuatu konsep yang telah dipelajari dengan baik. Mereka sangat asik dengan dunianya sendiri. Ketika pembelajaran berlangsung mereka tidak bisa berkonsentrasi terhadap materi yang diajarkan, menurut mereka hal ini sangat tidak menarik sehingga kemampuan dalam mengomunikasikan juga sangat rendah.

Hal inilah yang mendorong penulis untuk mendesain dan merancang sebuah media pembelajaran berupa kincir angin berbasis STEM untuk mengetahui peningkatan keterampilan mengomunikasikan pada siswa inklusi kelas 4 sekolah dasar.

\section{Belajar dan Pembelajaran}

Dalam dunia pendidikan istilah belajar dan pembelajaran sering didefinisikan dengan istilah yang sama, walaupun sebenarnya merupakan hal yang berbeda namun keberadaannnya saling berkaitan satu dengan 
lainnya. Menurut Kokom Komalasari (2015:2) Belajar adalah suatu perubahan dari ketidakmengertian menjadi lebih mengerti. Hal ini berdasarkan ciri-ciri dari proses belajar yaitu adanya kegiatan atau akitfitas yang bisa menghasilkan suatu perubahan secara aktual maupun potensial dalam diri seseorang.

Sedangkan pembelajaran menurut Rudi Rusilana (2012:1) merupakan aktifitas dari seseorang untuk mendapatkan ketrampilan, pengetahuan dan segala sesuatu yang bernilai positif dengan cara memanfaatkan berbagai sumber belajar yang ada. Media pembelajaran merupakan salah satu sumber belajar yang biasa menjembatani proses pembelajaran.

\section{Media Pembelajaran}

Media pembelajaran merupakan kata yang sudah tidak asing lagi dalam dunia pendidikan. Setiap proses pembelajaran selalu diperlukan media pembelajaran untuk memudahkan dan memaksimalkan proses pembelajaran yang dilaksanakan di kelas maupun kegiatan pembelajaran diluar kelas agar materi yang disampaikan oleh pendidik bisa terserap secara sempurna oleh pserta didik .

Menurut Heinich dalam Daryanto (2012:4) berasal dari kata media yang berarti penghubung atau perantara. Dapat diartikan sebagai penghubung atau perantara sehingga tercipta suatu komunikasi yang baik antara pemberi pesan dengan penerima pesan. Media pembelajaran dapat dijadikan sebagai sarana perantara dalam menyampaikan materi pembelajaran dan ketrampilan dalam kegiatan pembelajaran sehingga pembelajaran yang dilaksanakan menjadi lebih bermakna.

\section{Pendidikan Inklusi}

Anak-anak berkebutuhan khusus adalah anak-anak yang sangat istimewa. Walaupun banyak orang yang menganggap mereka berbeda dengan anak lainnya tetapi mereka memiliki kekhasan masing-masing yang sangat unik dan berbeda satu dengan lainnya. Anak-anak ini memiliki 
potensi yang luar biasa jika pendidik bisa mengasah kemampuan mereka dengan maksimal.

Menurut O'Neil dalam Budiyanto (2005:18) Pendidikan inklusi merupakan suatu program layanan pendidikan luar biasa yang memungkinkan semua anak-anak berkebutuhan khusus (luar biasa) dapat mendapatkan pendidikan di kelas bersama-sama dengan teman sebayanya. Tidak ada perbedaan pendidikan antara anak normal dan anak berkebutuhan khusus di sekolah inklusi. Mereka bisa belajar bersama dalam satu sekolahan, mereka bisa bermain bersama dan mereka bisa merasakan menjadi satu kesatuan dalam pendidikan di sekolah inklusi tersebut.

\section{Keterampilan Mengkomunikasikan}

Komunikasi merupakan hal yang wajib dikuasai dalam proses pembelajaran baik di dalam kelas maupun diluar kelas. Menurut Marfuah (2017) proses pembelajaran bisa terlaksana dengan baik karena adanya komunikasi yang bersifat intrapersonal maupun yang bersifat interpersonal. Kemampuan untuk berfikir, mengingat sesuatu serta melakukan persepsi merupakan kemampuan komunikasi yang bersifat intrapersonal. Sedangkan proses menyalurkan ide, gagasan tentang suatu informasi, menyimak argumentasi serta menghargai pendapat dari orang lain merupakan kemampuan komunikasi yang bersifat interpersonal.

Kemampuan berkomunikasi juga menjadi jembatan antara guru dan siswa dalam menemukan konsep yang tepat dalam suatu pembelajaran. Hal ini dikarenakan komunikasi bisa membantu dan memfasilitasi siswa dalam mengutarakan pendapat, gagasan serta informasi yang diharapkan. Ketrampilan mengomunikasikan perlu diasah dan diterapkan dalam setiap pembelajaran yang dilaksanakan. Dengan kemampuan berkomunikasi yang baik maka siswa akan memiliki rasa percaya diri dalam mengemukakakn pendapat serta argumentasinya sehingga menjadi sarana dalam pengembangan diri untuk menghargai pendapat orang lain yang berbeda-beda di sekitarnya. 
Ketrampilan berkomunikasi menjadi hal yang sangat penting dikuasai oleh siswa dalam menyambut era pendidikan di abad 21. Kompetensi belajar yang harus dikuasai yaitu kemampuan pemahaman yang tinggi, berpikir kritis, kemampuan dalam berkolaborasi dan berpikir tingkat tinggi.

\section{STEM}

Akhir-akhir ini istilah STEM menjadi istilah yang sangat fenomenal khusunya dalam dunia pendidikan. Sebenarnya apa definisi tiap kata dari STEM tersebut, kita akan membahasnya sebagai berikut :

a. Science, dalam pengertian awam science sering dihubungkan dengan mata pelajaran ilmu pengetahuan alam dimana materi yang dipelajari berkaitan dengan fenomena alam serta hal-hal yang terjadi di sekitar kita. Bisa juga dikatakan sebagai ilmu bumi dan antariksa

b. Technology : istilah teknologi selalu dikaitkan dengan hal-hal yang bersifat inovasi, pembaharuan, modifikasi yang tujuannya untuk lebih mempermudah pekerjaaan maupun kebutuhan manusia.

c. Engineering : merupakan suatu proses antara eksprerimen, praktik yang dilakukan melalui studi yang hasilnya akan diaplikasikan untuk pengembangan dalam memenuhi segala kebutuhan manusia.

d. Mathematics : kata-kata ini sangat familiar pada dunia pendidikan yaitu suatu ilmu yang berkaitan dengan pola, numerik dan korelasi.

Dunia pendidikan kita terus mengalami perkembangan, salah satunya adalah mengadobsi STEM sebagai salah satu tujuan dalam pencapaian kegiatan pembelajaran yang dilaksanakan.

Menurut Bybee (2013) bahwa tujuan penerapan pendidikan dengan konten STEM mengacu pada :

a. Pengetahuan, dengan menerapkan pembelajaran berbasis STEM diharapkan peserta didik memiliki aspek kognitif, afektif dan psikomotor untuk mengidentifikasi setiap masalah dengan hal-hal yang bersifat ilmiah. 
b. Pembentukan kepribadian yang berbasis STEM akan membentuk pola piker secara inkuiri dalam perolehan pengetahuaannya.

c. Individu yang terbiasa melakukan sesuatu berbasis STEM maka akan membentuk intelektual yang berbudaya terhadap lingkungan.

Seseorang yang peduli, konstrukrtif dan reflektif merupakan pribadi yang terikat dengan pengetahuan alam, teknologi, engineering dan mathematic dalam kehidupannya.

\section{B. Metode}

Media pembelajaran kincir angin berbasis ciber STEM ini dikembangkan melalui penelitian dengan menggunakan metode penelitian dan pengembangan. Menurut Borg \& Gall dalam Wina Sanjaya (2013:133), merinci langkah-langkah dalam penelitian dan pengembangan:

1. Riset dan pengumpulan informasi termasuk studi literatur dan observasi

Pada awal pengumpulan informasi peneliti melakukan observasi kelas untuk mendapatkan data-data yang bisa menjadi acuan dalam mendesain dan merancang proses pembelajaran. Termasuk di dalamnya menggali informasi tentang keterampilan mengomunikasikan pada siswa inklusi di kelas 4 sekolah dasar.

Setelah melaksanakan analisis pembelajaran ternyata sebagian besar siswa kurang tertarik dengan pembelajaran yang ada di kelas sehingga kemampuan mengomunikasikan kurang berkembang dengan baik. Siswa cenderung pasif dan tetap duduk di tempatnya tanpa bersemangat melakukan aktifitas apapun yang berkaitan dengan pembelajaran. Ketika harus diwajibkan untuk mengomunikasikan ke depan kelas atau berdiskusi dengan teman sekelasnya mereka tidak bisa mengungkapkan dengan baik secara lisan maupun secara tertulis.

2. Perencanaan

Setelah mengumpulkan data-data yang ada maka penulis berusaha memperbaiki proses pembelajaran yang dilaksanakan di sekolah inklusi khususnya pada siswa di kelas 4 sekolah dasar. Sesuai dengan 
analisa kebutuhan dari ketujuh peserta didik yang memiliki berbagai macam karakteristik dan kekhasan masing-masing. 4 peserta didik di sekolah inklusi ini adalah mereka yang menyandang tuna grahita ringan dan sedang, satu orang merupakan peserta didik dengan indikasi Borderline/lambat, satu lagi merupakan peserta didik dengan indikasi Slow Learner $(\mathrm{H})$ dan satu lagi merupakan peserta didik dengan indikasi Low Average/di bawah rata-rata.

Penulis berusaha menciptakan suatu pembelajaran yang dapat meningkatkan keterampilan mengomunikasikan pada siswa inklusi dengan lebih memaksimalkan penggunaan media pembelajaran. Dengan mengacu pada data-data yang ada maka penulis merancang dan menciptakan sebuah media pembelajaran berupa kinvir angin berbasis STEM yang memungkinkan peserta didik terlibat secara langsung dalam menemukan suatu konsep dan melakukan aktivitas yang mengarah pada kemampuan keterampilan mengomunikasikan. Tanpa terasa permainan yang mereka lakukan secara berkelompok merupakan sebuah pembelajaran yang di dalamnya sarat akan ilmu pengetahuan.

3. Pengembangan produk awal.

a. Setelah melakukan penelitian dan mengumpulkan data-data yang ada di awal pembuatan media pembelajaran kincir angin berbasis STEM ini penulis memiliki ide untuk mewujudkan suatu alat sederhana yang dapat menghasilkan energi listrik dari putaran kincir angin .

b. Penulis mengkomunikasikan dan berdiskusi dengan teman sejawat tentang ide pembuatan media pembelajaraan tersebut.

c. Terdapat beberapa masukan dan saran dari teman sejawat.

d. Penulis berusaha mencari informasi dengan cara googling di internet tentang pembuatan media pembelajaran kincir angin.

e. Diawal pembuatan media pembelajaran kincir angin berbasis STEM ini penulis menggunakan botol bekas air mineral sebagai bahan dasar pembuatan kincir angin. 
4. Uji lapangan produk awal

a. Uji coba produk awal tentang media pembelajaran kincir angin ini dilakukan di sekolah dengan dibantu oleh rekan-rekan guru sebagai sasaran kegiatan.

b. Hasil demonstrasi dari pemanfaatan media pembelajaran kincir angin ini belum bisa maksimal karena kincir angin yang terbuat dari botol bekas air mineral tidak mampu memutar dinamo yang ada sehingga tidak menghasilkan energi listrik.

5. Revisi produk awal

a. Revisi dari produk media pembelajaran kincir angin ini dilakukan dengan cara mengganti kincir angin yang tadinya dari botol bekas air mineral diganti dengan baling-baling dari kipas angin yang sudah rusak.

b. Kipas angin yang sudah tidak dapat digunakan diambil balingbalingnya dan dipasangkan ke kincir angin dalam media ini. Terdapat pengunci baling-baling yang terbuat dari besi agar kincir angin yang dipasang bisa lebih kuat posisinya.

6. Uji lapangan revisi produk

Setelah adanya revisi dari produk awal maka diadakan uji lapangan media pembelajaran yang telah diganti baling-balingnya. Ternyata putaran baling-baling yang dihasilkan belum bisa membuat lambu lcd menyala dengan terang walaupun kipas angin sebagai pendorong putran baling-baling sudah sangat kuat.

7. Revisi produk berdasarkan hasil uji produk

Pada revisi produk yang kedua ini penulis mengganti lampu led dengan kapasitas tenaga listrik yang lebih kecil dengan menambahkan aksesoris pada ujung lampu yang berbentuk payung.

8. Uji lapangan pada skala yang lebih luas

Pada saat uji lapangan ini media pembelajaran kincir angin berbasis STEM ini sangat memuaskan. Putaran baling-baling pada kincir angin dengan bantuan dorongan angin dari kipas angin dapat 
menghasilkan energi listrik yang akhirnya dapat menyalakan lampu led dengan lebih terang jika putaran kipas angin dibuat lebih kencang.

9. Revisi akhir produk berdasarkan analisis data pada uji lapangan terakhir.

Puncak dari revisi media pembelajaran ini adalah pemberian aksesoris pada paralon yang digunakan dan pada triplek sebagai pencari arah angin agar penampilan media pembelajaran ini lebih menarik bagi peserta didik.

10. Diseminasi dan melaporkan produk akhir hasil penelitian dan pengembangan.

Diseminasi media pembelajaran kincir angin berbasis STEM ini dilaksanakan oleh penulis dengan melibatkan rekan-rekan guru dari sekolah inklusi.

\section{Hasil dan Pembahasan}

Media pembelajaran kincir angin berbasis STEM ini adalah sebuah media pembelajaran yang terdiri atas baling-baling yang bisa menggerakkan dynamo yang dapat menghasilkan energi listrik. Media pembelajaran kincir angin ini digunakan dalam pembelajaran tema Selalu Berhemat Energi pada siswa inklusi kelas 4 sekolah dasar. Adapun aplikasi praktis dari media pembelajaran adalah sebagai berikut :

1. Pendidik memberi informasi tentang materi yang akan dipelajari oleh peserta didik.

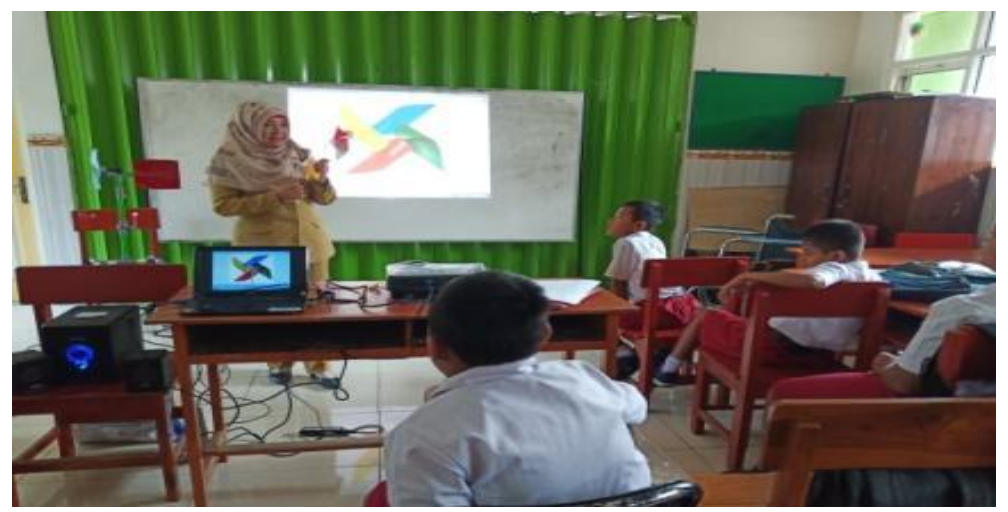


2. Pendidik menyiapkan media pembelajaran yang akan dipelajaari peserta didik

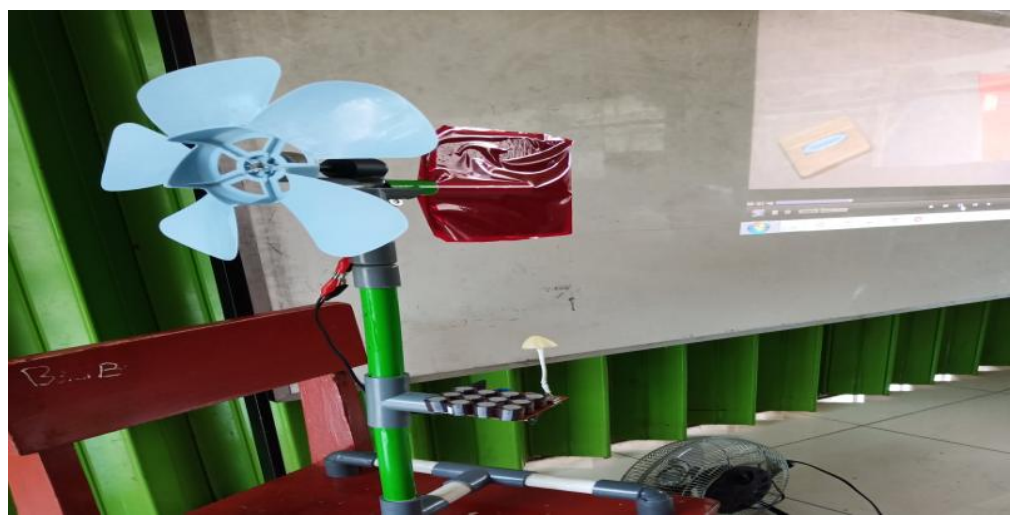

3. Pendidik menstimulasi pengetahuan peserta didik dengan memutar sebuah video pembelajaran yang berkaitan dengan energi listrik.

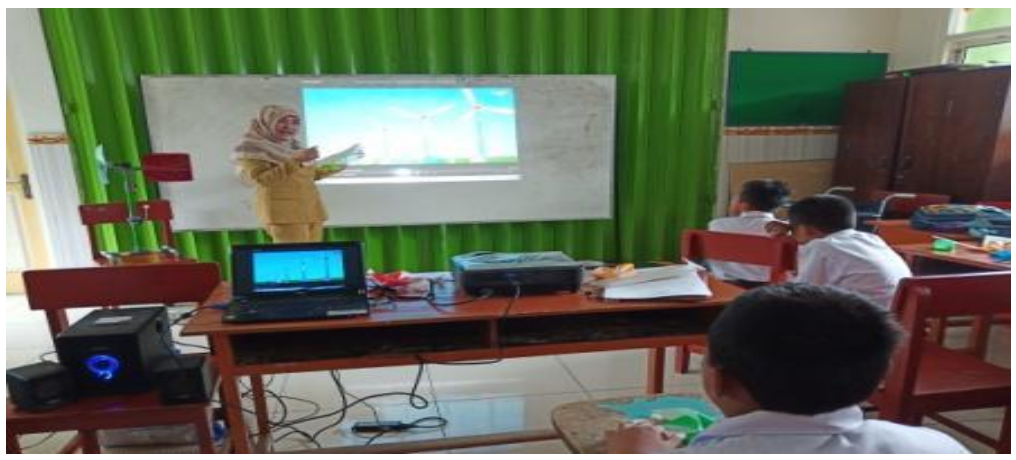

4. Peserta didik dibantu oleh pendidik membuat kincir angin dari kertas.

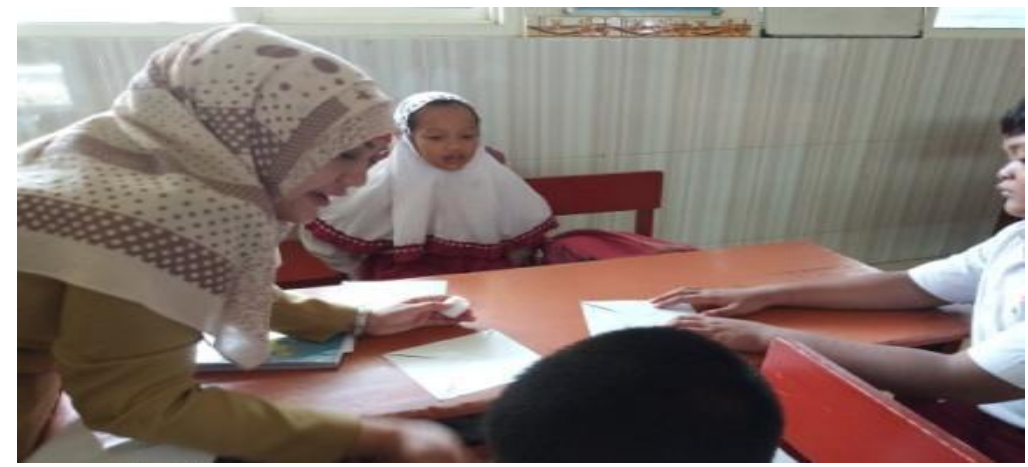

5. Peserta didik dengan arahan dari pendidik mendemonstrasikan tentang proses terjadinya energi listrik dari putaran baling-baling. 


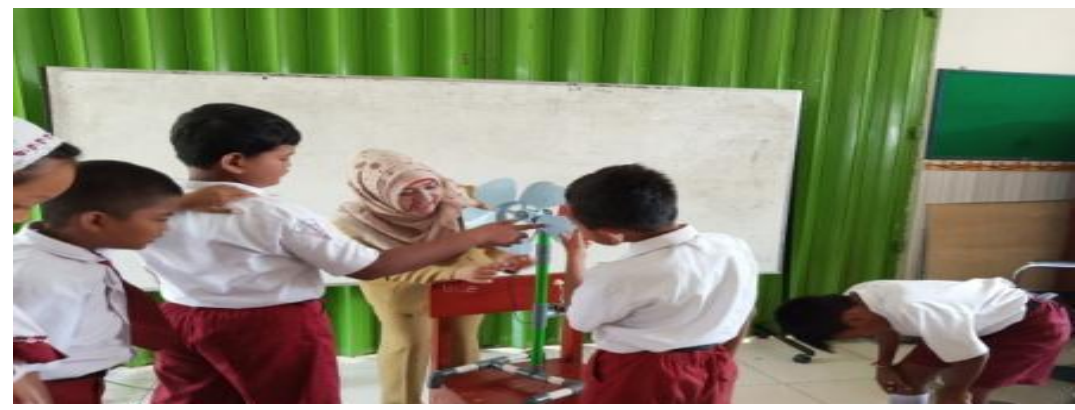

6. Peserta didik menyalakan kipas angin untuk memutar baling-baling yang ada pada kincir angin

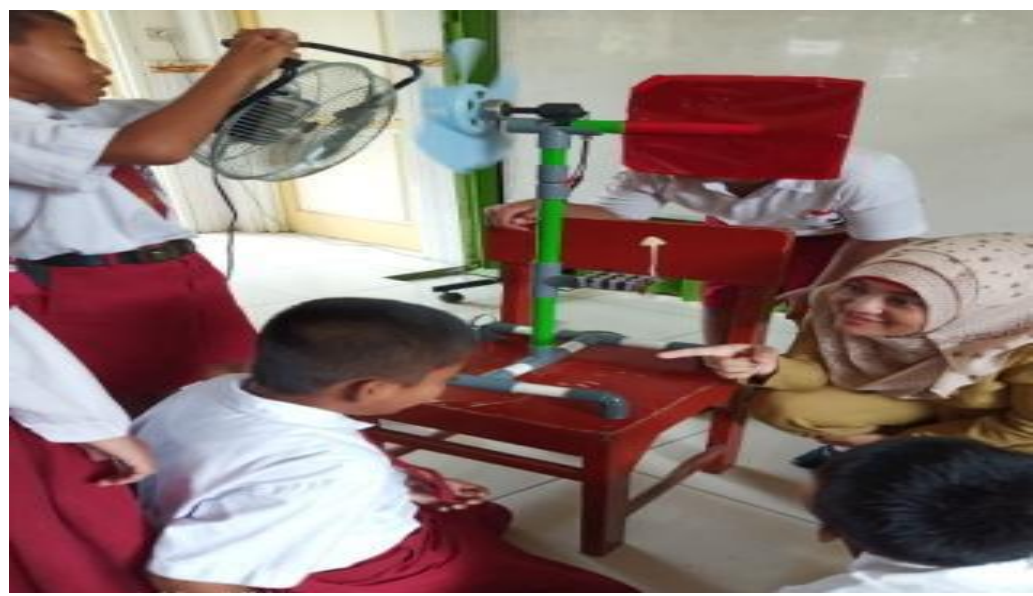

7. Peserta didik mengamati lampu led yang menyala akibat dari gerakan baling-baling kincir angin

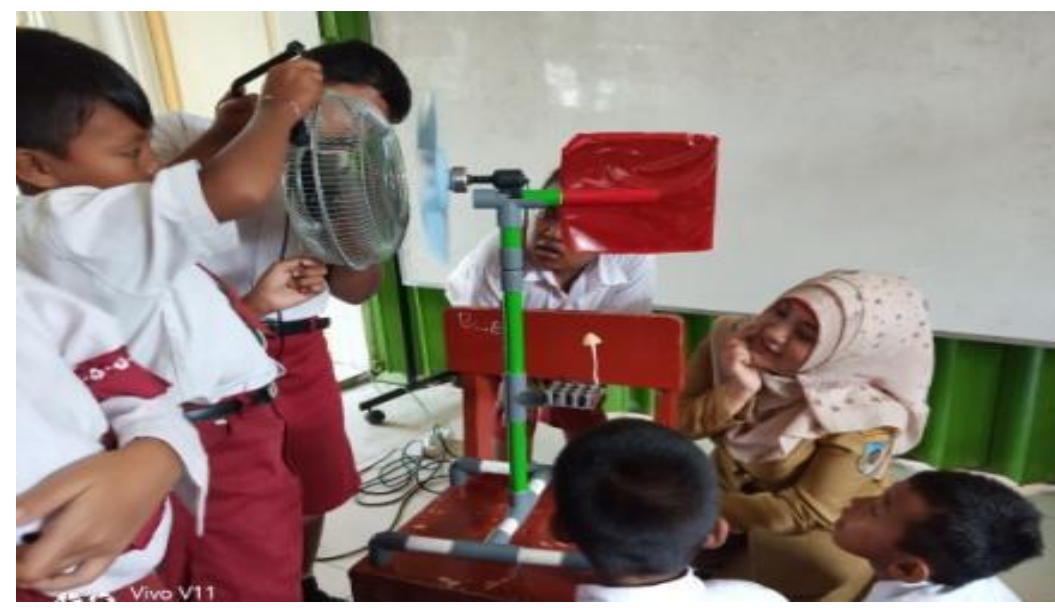


8. Peserta didik menulis kan beberapa kalimat tentang kincir angin

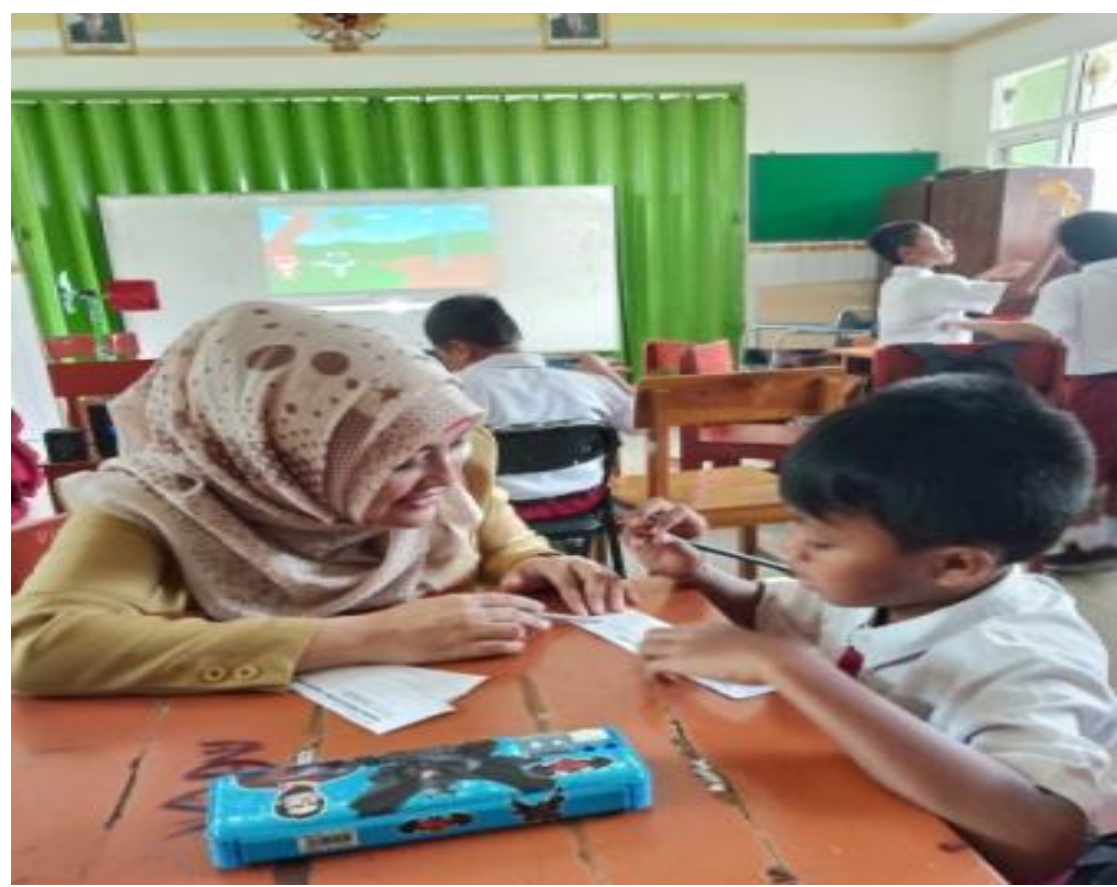

9. Pendidik memberikan beberapa pertanyaan terkait dengan kincir angin

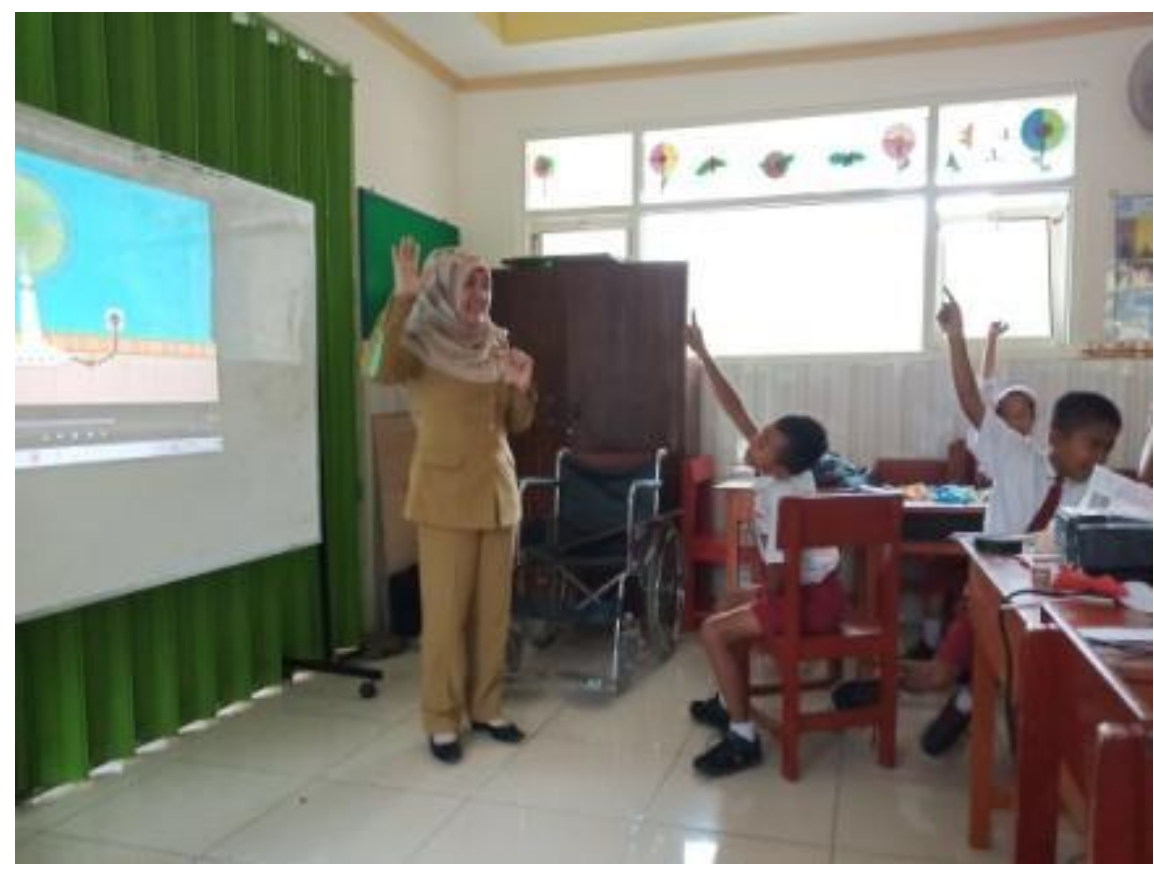


10. Peserta didik dibantu oleh pendidik merangkum materi

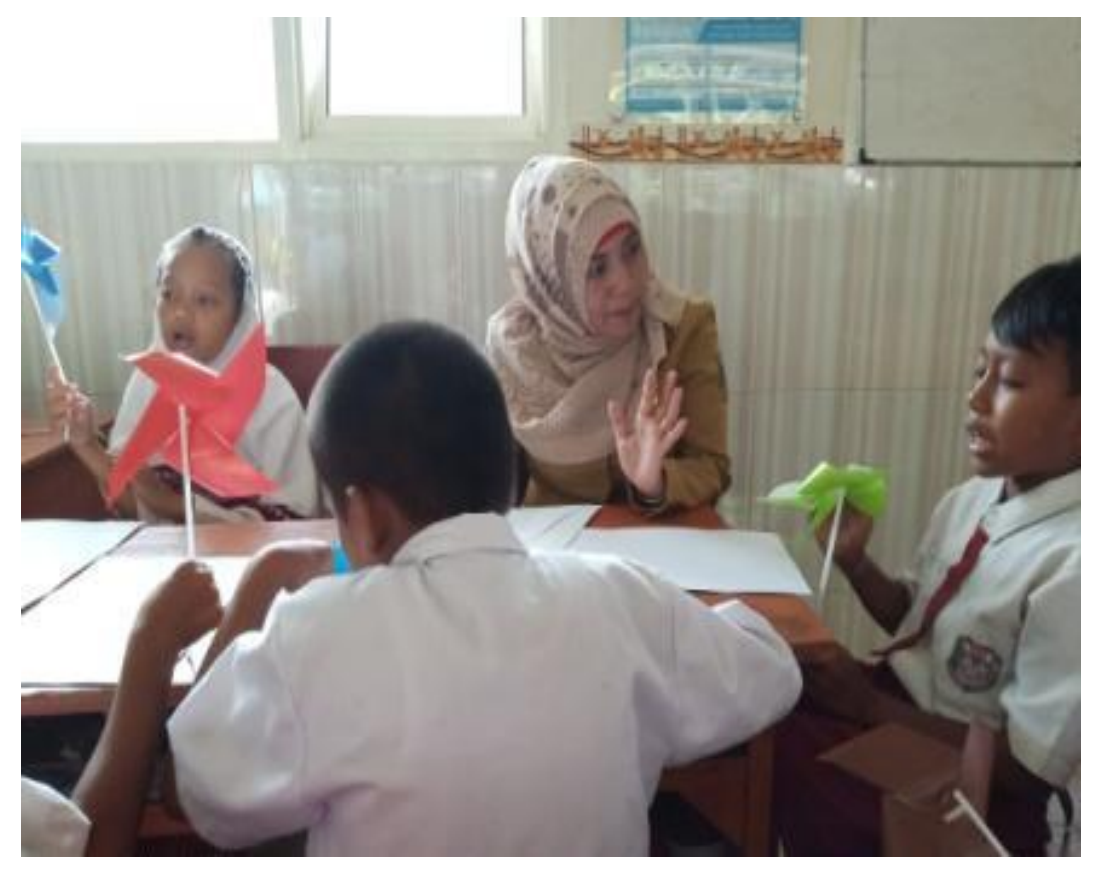

11. Peserta didik bersama-sama pendidik bermain diluar kelas dengan mencoba kincir angin kertas yang mereka buat.

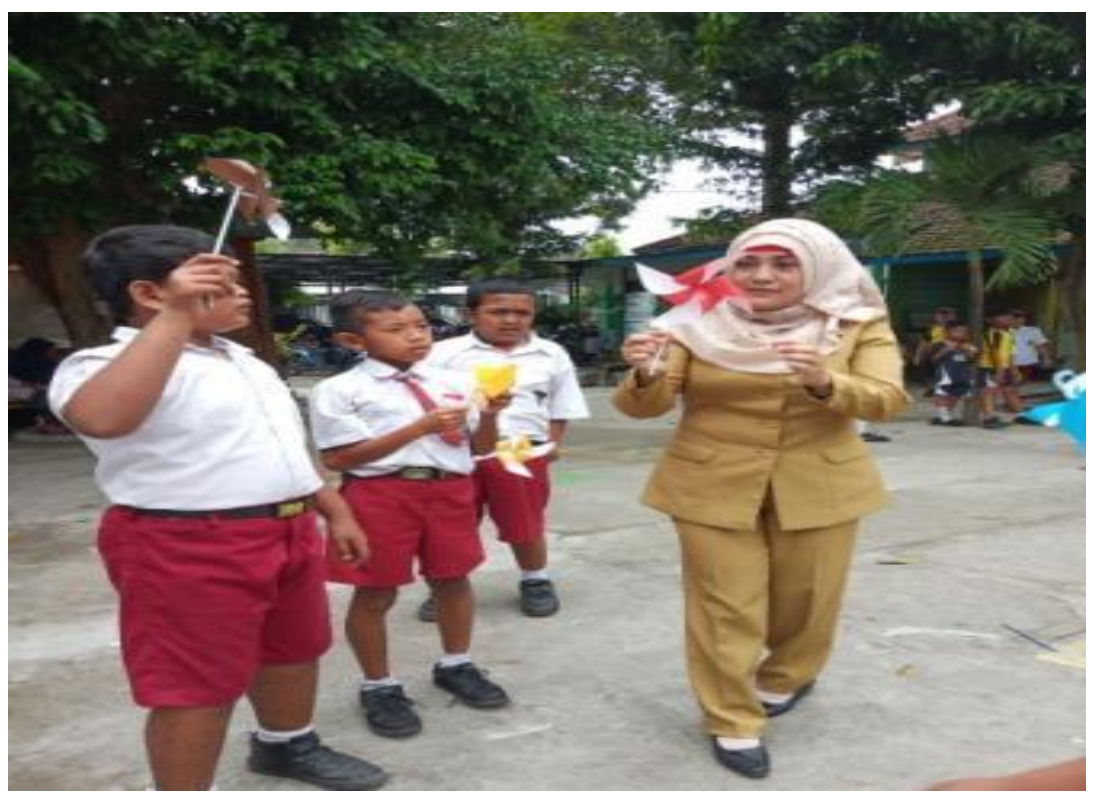


Dari serangkaian kegiatan pembelajaran dengan menggunakan media pembelajaran kincir angin berbasis STEM pada siswa inklusi kelas 4 sekolah dasar maka dapat direfleksikan sebagai berikut :

1. Sebelum menggunakan media pembelajaran kincir angin berbasis STEM nilai rata-rata siswa inklusi kelas 4 sekolah dasar adalah 66,67 .

2. Setelah pembelajaran dengan menggunakan media pembelajaran kincir angin berbasis STEM terdapat peningkatan nilai rata-rata menjadi 85,71.

3. Semua data-data yang telah diperloleh dalam pembelajaran dapat disajikan dalam bentuk diagram batang di bawah ini.

Grafik Hasil Observasi Keterampilan Mengkomunikasikan Sebelum
Dan Sesudah Menggunakan Media Pembelajaran Kincir Angin

\section{|| il II I| i| i|}

\section{Grafik Kesan Peserta Didik}

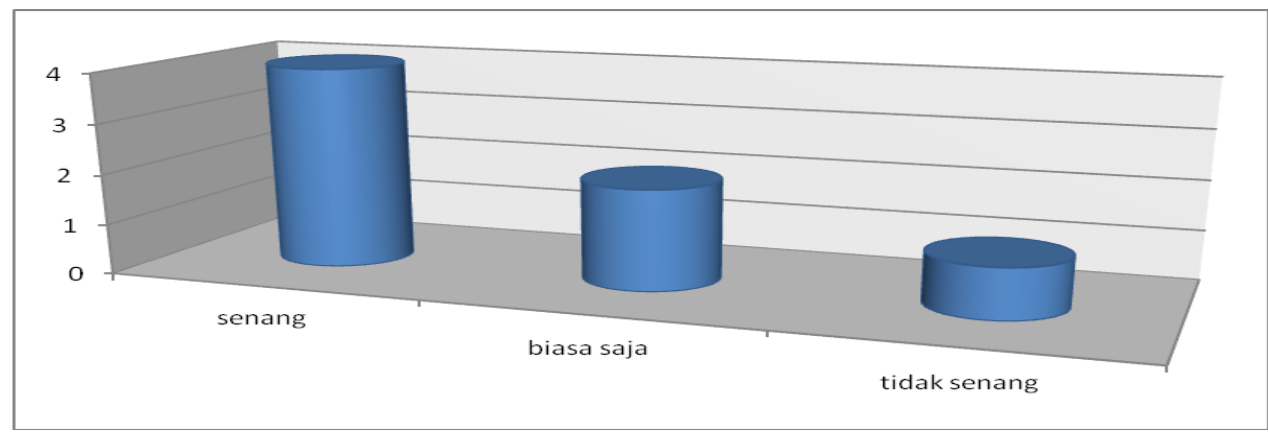

Dari hasil refleksi pada tabel dan data-data yang telah disajikan maka dapat disimpulkan bawa penggunaan media pembelajaran kincir 
angin berbasis STEM dapat meningkatkan ketrampilan mengomunikasikan pada siswa inklusi kelas 4 sekolah dasar.

DISEMINASI Sebagai tindak lanjut dari aplikasi pembelajaran dengan menggunakan media pembelajaran kincir angin berbasis STEM maka penulis mengadakan diseminasi kepada rekan-rekan guru di sekolah inklusi. Hal ini sengaja dilakukan mengingat media pembelajaran kincir angin berbasis STEM ini terbukti dapat meningkatkan keterampilan mengomunikasikan pada siswa inklusi khususnya pada siswa kelas 4 sekolah dasar.

\section{Penutup}

Dalam proses pembelajaran baik di dalam kelas maupun di luar kelas pendidik sebaiknya menggunakan media pembelajaran yang tepat agar memudahkan penyampaian materi dari pendidik kepada peserta didiknya. Media pembelajaran kincir angin berbasis STEM merupakan sebuah media pembelajaran yang berupa baling-baling yang berputar dengan bantuan kipas angin sebagai energi listriknya yang dapat menghasilkan energi listrik dalam skala yang sangat kecil. Penerapan dan penggunaan media pembelajaran kincir angin berbasis STEM ini sangat sederhana dan sangat mudah dalam pengoperasiannya seperti permainan yang menarik bagi peserta didik. Penggunaan media pembelajaran kincir angin berbasis STEM ini mampu meningkatkan ketrampilan mengomunikasikan pada peserta didik khususunya pada siswa inklusi kelas 4 sekolah dasar berdasarkan peningkatan hasil rata-ratanya sebelum dan sesudah menggunakan media pembelajaran yang telah dilaksanakan.

\section{Ucapan Terimakasih}

Ucapan terimakasih kami haturkan sebesar-besarnya keluarga besar SD Negeri Minggiran I yang telah memberikan kesempatan dan apresiasi kepada peneliti untuk mengembangkan diri serta memberikan sarana dan prasarana dalam peningkatan mutu pendidikan khususnya pendidikan inklusi. 
Ida Sri Astutik

\section{Daftar Referensi}

Budiyanto. (2005). Pengantar Pendidikan Inklusif Berbasis Budaya Lokal. Jakarta: Depdiknas

Cholik Mutohir Toho., \& Gusril. (2004). Perkembangan Motorik pada Masa anak-anak. Jakarta. Depdikbud RI

Bybee, R. (2013). The case for STEM Education, Challeges and Opportunity, NSTA press. Arlington. Virginia

Daryanto. (2012). Media Pembelajaran. Bandung : PT Satu Nusa

Dedy Kustawan. (2012). Pendidikan Inklusif dan Upaya Implementasinya. Jakarta : Luxima

Deriyati, Putri. (2013). Pengaruh Keterampilan Berkomunikasi Sains Menggunakan Pendekatan Pembelajaran Multiple Representations terhadap Literasi sains Siswa SMP. Bandar Lampung : Universitas Lampung

Djamaah, Syaiful B., \& Azwan Z. 2010. Strategi Belajar Mengajar. Jakarta : Rineka Cipta

Indiyanto. (2013). Implementasi Pendidikan Inklusif. Surakarta : FKIP UNS

Komalasari Kokom. (2015). Pembelajaran Konstektual Konsep dan Aplikasi. Bandung: Refika Aditama

Marfuah. (2017). Meningkatkan Keterampilan Komunikasi Peserta Didik. Volume 26, 148-160

Nurlaila, R., Enawaty, E., \& Lestari.I. (2015). Upaya Meningkatkan Keterampilan Komunikasi Siswa Melalui Model Pembelajaran ThinkTalk-Write.

Puji Astuti., \& Endah Nur Endah. (2015). "Balloon Powered Car" sebagai Media Pembelajaran IPA Berbasis STEM (science, technology, engineering, and mathematics). Prosiding Simposium Nasional Inovasi dan Pembelajaran Sains 2015 (snips 2015), Bandung 8 dan 9 Juni 2015

Rusilana Rudi., Riyana Cepi. (2012). Media Pembelajaran. Bandung: Wacana Prima

Suwarma. R. Irma (2015), Research on Theory and Practice STEM Education Implementation in Japan and Indonesia using Multiple Intelligences 
Vol. 4, No. 3, November 2020 